\title{
Resistance to Oleandomycin in Streptomyces antibioticus, the Producer Organism
}

\author{
By J. F. FIERRO, C. HARDISSON AND J. A. SALAS* \\ Departamento de Microbiologia, Universidad de Oviedo, 33006 Oviedo, Spain
}

(Received 1 October 1986; revised 22 January 1987)

\begin{abstract}
Resistance to oleandomycin in Streptomyces antibioticus, the producer organism, was studied. The organism was highly resistant in vivo to the antibiotic but sensitive to other macrolides and lincosamides. Protein synthesis in vivo by mycelium of $S$. antibioticus was more resistant to oleandomycin than that by mycelium of Streptomyces albus G, an oleandomycin-sensitive strain, and this resistance was dependent on the age of the culture, older mycelium of $S$. antibioticus being more resistant to oleandomycin than young mycelium. $\left[{ }^{3} \mathrm{H}\right]$ Oleandomycin was capable of binding to the same extent to the $50 \mathrm{~S}$ subunits of the ribosomes of both organisms. Oleandomycin also inhibited in vitro protein synthesis by ribosomes obtained from an oleandomycin-production medium at the time when maximum levels of oleandomycin were being produced. A clear difference between the ability of the two organisms to incorporate exogenous oleandomycin was observed. Thus, while $S$. albus G took up oleandomycin, $S$. antibioticus showed a decreased permeability to the antibiotic, suggesting a role for cell permeability in self-resistance.
\end{abstract}

\section{INTRODUCTION}

Macrolide antibiotics are a class of compounds containing a macrocyclic lactone ring (of 12 , 14 and 16 residues) to which one or more amino sugars and/or deoxysugars are attached. These antibiotics inhibit protein synthesis by acting on the 50S ribosomal subunit (Gale et al., 1981). Among the macrolides, erythromycin is one of the most commonly employed. Resistance to this antibiotic in Escherichia coli has been found to be due to alterations in either of the ribosomal proteins L4 or L22 (Gale et al., 1981) and, more recently, to enzymic hydrolysis of the antibiotic (Barthelemy et al., 1984). In clinical isolates of Staphylococcus aureus (Lai \& Weisblum, 1971) and of Streptococcus pyogenes (Clewell \& Franke, 1974), a relationship has been demonstrated between resistance to erythromycin and a characteristic pattern of coresistance to other macrolides, lincosamides and B-type streptogramins, which was termed the MLS-phenotype. This phenotype has been shown to depend on the presence of $N^{6}$-dimethyladenine in 23S ribosomal RNA (Lai et al., 1973). Most of the macrolides are produced by Streptomyces species and these organisms are usually highly resistant to their endogenous antibiotics (Graham \& Weisblum, 1979). However, among the streptomycetes, only $S$. erythraeus (an erythromycin producer) has been reported to show the MLS-phenotype, which was also associated with the presence of a single residue of $N^{6}$-dimethyladenine at position 2058 within $23 \mathrm{~S}$ ribosomal RNA (Skinner \& Cundliffe, 1982; Skinner et al., 1983). Oleandomycin is a macrolide very closely related to erythromycin in both its structure and its mode of action (Gale et al., 1981). However, although the producer organism, $S$. antibioticus, is resistant to oleandomycin, it does not show the MLS-phenotype and is sensitive to erythromycin. Given the close structural similarities between oleandomycin and erythromycin, this is surprising. Accordingly, it was decided to study the basis of resistance to oleandomycin in $S$. antibioticus.

Abbreviation: MLS, macrolide-lincosamide-streptogramin (B-type). 


\section{METHODS}

Bacterial strains and media. The following Streptomyces species were used: Streptomyces lividans TK21 and Streptomyces albus G, kindly provided by Professor D. A. Hopwood, S. erythraeus NRRL 2338 and S. antibioticus ATCC 11891 (oleandomycin producer). The organisms were usually grown in YEME liquid medium consisting of $\left(\mathrm{g}^{-1}\right)$ : yeast extract, 3.0 ; malt extract, 3.0 ; peptone, $5 \cdot 0 ;$ glucose, $10 \cdot 0$. The medium $(500 \mathrm{ml})$ was inoculated with a spore suspension and incubated at $35^{\circ} \mathrm{C}$ for $36 \mathrm{~h}$ in an orbital Gallenkamp shaker at 200 r.p.m. The mycelia were harvested by centrifugation $(12500 \mathrm{~g}$ for $15 \mathrm{~min})$, washed twice in buffer A (10 mM-HEPES/KOH pH 7.5 at $20^{\circ} \mathrm{C}, 10 \mathrm{mM}-\mathrm{MgCl}_{2}, 1 \mathrm{M}-\mathrm{KCl}$ and $5 \mathrm{mM}-2$-mercaptoethanol), once in buffer B (50 mM-HEPES/KOH pH 7.5 at $20^{\circ} \mathrm{C}, 10-\mathrm{mM}-\mathrm{MgCl}_{2}, 60 \mathrm{mM}-\mathrm{NH}_{4} \mathrm{Cl}$ and $5 \mathrm{mM}$-2-mercaptoethanol) and finally resuspended in buffer $\mathrm{B}$ at $0.5 \mathrm{~g}$ wet wt ml-1. Micrococcus luteus ATCC 10240 was grown overnight at $37^{\circ} \mathrm{C}$ in Mueller-Hinton Broth (Difco). The cells were then collected by centrifugation, suspended in $20 \%(\mathrm{v} / \mathrm{v})$ glycerol and kept frozen at $-20^{\circ} \mathrm{C}$ until use.

Determination of the MIC values and tests for antibiotic production by $S$. antibioticus. Conditions were similar to those previously described using $M$. luteus as an indicator organism (Blanco et al., 1984).

Assay of in vivo protein synthesis. The organism was grown in a minimal medium containing $\left(\mathrm{g} \mathrm{l}^{-1}\right): \mathrm{glucose}, 10 \cdot 0$; asparagine, $2.0 ;\left(\mathrm{NH}_{4}\right)_{2} \mathrm{SO}_{4}, 2.0 ; \mathrm{K}_{2} \mathrm{HPO}_{4}, 4.3 ; \mathrm{KH}_{2} \mathrm{PO}_{4}, 0.82 ; \mathrm{FeSO}_{4} .7 \mathrm{H}_{2} \mathrm{O}, 0.01 ; \mathrm{MgSO}_{4} .7 \mathrm{H}_{2} \mathrm{O}, 0.5 . \mathrm{At}$ various time intervals, samples $(10 \mathrm{ml})$ were centrifuged, resuspended in fresh medium and further samples $(0.5 \mathrm{ml})$ were then incubated for $5 \mathrm{~min}$ at $35^{\circ} \mathrm{C}$ in the absence or presence of different concentrations of oleandomycin followed by pulse-labelling for $20 \mathrm{~min}$ with L- $[4,5-3 \mathrm{H}]$ leucine $\left(142 \mathrm{Ci} \mathrm{mmol}^{-1}, 5 \cdot 25 \mathrm{MBq} \mathrm{mmol}^{-1}\right)$ at $1 \mu \mathrm{Ci} \mathrm{m}^{-1}$ (final concentration). The incorporation was stopped by the addition of $1.5 \mathrm{ml}$ ice-cold $20 \%(\mathrm{w} / \mathrm{v}) \mathrm{TCA}$ $\left(15 \%\right.$ final concentration). After $30 \mathrm{~min}$ at $4{ }^{\circ} \mathrm{C}$, the samples were heated for $15 \mathrm{~min}$ at $90^{\circ} \mathrm{C}$, cooled on ice and filtered through Whatman GF/C filters. The radioactivity in the dried filters was estimated in a Beckman LS100C liquid-scintillation spectrophotometer using a toluene-based scintillation fluid.

Isolation of ribosomes. The mycelia were broken by ultrasound using five $20 \mathrm{~s}$ pulses in a $150 \mathrm{~W}$ ultrasonic disintegrator and the extract was centrifuged at $30000 \mathrm{~g}$ for $30 \mathrm{~min}$. The supernatant was then centrifuged at $320000 \mathrm{~g}$ for $2 \mathrm{~h}$ in a Beckman 75 Ti rotor. The sedimented ribosomes were suspended in buffer $\mathrm{B}$ and then layered over buffer C (50 mM-HEPES/KOH pH 7.5 at $20^{\circ} \mathrm{C}, 30 \mathrm{mM}-\mathrm{MgCl}_{2}, 1 \mathrm{M}-\mathrm{NH}_{4} \mathrm{Cl}$ and $5 \mathrm{~mm}$-2-mercaptoethanol) containing $40 \%(w / v)$ sucrose and centrifuged at $320000 \mathrm{~g}$ for $2 \mathrm{~h}$ at $4{ }^{\circ} \mathrm{C}$. These 'high salt washed' ribosomes were finally suspended in buffer $\mathrm{B}$ and stored at $-70^{\circ} \mathrm{C}$.

Preparation of $\left[{ }^{3} \mathrm{H}\right]$ oleandomycin. Spores of $\mathrm{S}$. antibioticus were used to inoculate $100 \mathrm{ml}$ of the minimal medium described above. After $16 \mathrm{~h}$ at $35^{\circ} \mathrm{C}, 0.5 \mathrm{mCi} \mathrm{L}-\left[\right.$ methyl $\left.-{ }^{3} \mathrm{H}\right]$ methionine $\left(89 \mathrm{Ci} \mathrm{mmol}^{-1}, 3.3 \mathrm{TBq}_{\mathrm{mmol}}^{-1}\right) \mathrm{was}^{-1}$ added and incubation continued for a further $2 \mathrm{~d}$. The culture was then centrifuged, and the supernatant was brought to $\mathrm{pH} 9.8$ with $\mathrm{KOH}$ and extracted five times with chloroform $(1: 1, \mathrm{v} / \mathrm{v})$. The extract was flash evaporated and the residue was taken up in DMSO and kept frozen at $-20^{\circ} \mathrm{C}$. Purity of the radioactive material thus obtained and its correspondence with commercial oleandomycin was checked by descending paper chromatography on Whatman $3 \mathrm{MM}$ for $15 \mathrm{~h}$ using as solvent $\mathrm{n}$-butanol/acetic acid/water $(60: 20: 20$, by vol. $)$. After drying, the chromatogram was cut into $1 \mathrm{~cm}$ strips and the radioactivity in each was determined. Commercial oleandomycin was run in a parallel track and located by staining in $10 \%(\mathrm{w} / \mathrm{v}) \mathrm{H}_{2} \mathrm{SO}_{4}$ and heating the paper for $20 \mathrm{~min}$ at $80^{\circ} \mathrm{C}$.

Binding of $\left.{ }^{3} \mathrm{H}\right]$ bleandomycin to ribosomes. The ability of ribosomes to bind $\left[{ }^{3} \mathrm{H}\right]$ oleandomycin was determined by two methods. (1) Sucrose gradient centrifugation. A sample of $70 \mathrm{~S}$ ribosomes $\left(5 A_{254}\right.$ units - approximately $150 \mathrm{pmol}$ ) was incubated at room temperature for $10 \mathrm{~min}$ with [ ${ }^{3} \mathrm{H}$ ]oleandomycin [approximately $167 \mathrm{pmol}$; 598 c.p.m. (pmol) ${ }^{-1}$ ]. The incubation mixture was layered over a $5 \mathrm{ml} \mathrm{sucrose} \mathrm{density} \mathrm{gradient}(10-30 \%$ sucrose) in buffer $\mathrm{D}\left(50 \mathrm{~mm}-\mathrm{HEPES} / \mathrm{KOH} \mathrm{pH} 7.5\right.$ at $20^{\circ} \mathrm{C}, 1 \mathrm{mM}-\mathrm{MgCl}_{2}, 150 \mathrm{mM}-\mathrm{NH}_{4} \mathrm{Cl}$ and $5 \mathrm{~mm}-2$-mercaptoethanol) and centrifuged at $240000 \mathrm{~g}$ for $3 \mathrm{~h}$ at $4^{\circ} \mathrm{C}$ in a Beckman SW 50.1 rotor. After centrifugation, the bottom of the tube was punctured, fractions $(0.2 \mathrm{ml})$ were collected and the $A_{254}$ was monitored continuously. Radioactivity in samples of the different fractions was determined. (2) Gel filtration. After incubation of the ribosomes with [ $\left.{ }^{3} \mathrm{H}\right]-$ oleandomycin as described above, the reaction mixture was applied to a column (Bio Gel $\mathrm{A} 0.5 \mathrm{~m}$; $0.6 \mathrm{~cm} \times 30 \mathrm{~cm}$ ) and eluted with several volumes of buffer B. $A_{254}$ values and radioactivity were determined in the different fractions.

Coupled transcription translation. The sensitivity of ribosomes to oleandomycin was assayed by the coupled transcription-translation system described by Thompson et al. (1984) using extracts of $S$. lividans, was used, with the modification that the $S 30$ was centrifuged at $320000 \mathrm{~g}$ for $2 \mathrm{~h}$ at $4{ }^{\circ} \mathrm{C}$ in a Beckman $75 \mathrm{Ti}$ rotor to remove the ribosomes. The reaction mixture was supplemented with a crude preparation of initiation factors obtained by 'high salt washing' of $S$. lividans ribosomes. Proteins removed from ribosomes in this way were fractionated using $\left(\mathrm{NH}_{4}\right)_{2} \mathrm{SO}_{4}$ at $80 \%$ saturation and the precipitate was dialysed against $10 \mathrm{~mm}-\mathrm{HEPES} / \mathrm{KOH} \mathrm{pH} 7.5$ at $20^{\circ} \mathrm{C}$ and $5 \mathrm{mM}$-2-mercaptoethanol. Plasmid-dependent protein synthesis was measured by the incorporation of $\mathrm{L}-\left[{ }^{35} \mathrm{~S}\right]-$ methionine (1255 Ci mmol-1; 46.4 $\mathrm{TBq} \mathrm{mmol}^{-1}$ ) into TCA-insoluble material and was dependent on the addition of exogenous ribosomes (see legend to Fig. 5).

Oleandomycin uptake studies. YEME liquid medium $(100 \mathrm{ml})$ was inoculated with a spore suspension and 
incubated with shaking at $35^{\circ} \mathrm{C}$ for $16 \mathrm{~h}$. Then, the culture was centrifuged and the mycelium was suspended in $3 \mathrm{ml}$ of the same medium. Oleandomycin was added at various concentrations and the cultures were incubated with shaking at $35^{\circ} \mathrm{C}$. At various times of incubation, $500 \mu \mathrm{l}$ samples were removed and centrifuged in an Eppendorf minifuge at $42500 \mathrm{~g}$ for $5 \mathrm{~min}$. The amount of oleandomycin in the supernatant was determined by bioassay using $M$. luteus as test organism, hence the amount of drug taken up by the mycelium could be determined by difference.

\section{RESULTS}

Susceptibility of protein synthesis in vivo

$S$. antibioticus ATCC 11891, the producer of oleandomycin, is resistant to oleandomycin (MIC $>200 \mu \mathrm{g} \mathrm{ml}^{-1}$ ) but sensitive to other MLS antibiotics, e.g. erythromycin, carbomycin, spiramycin, methymycin and lincomycin (MICs 30,1,1,40 and $20 \mu \mathrm{g} \mathrm{ml}^{-1}$ respectively). Since oleandomycin inhibits protein by acting on the $50 \mathrm{~S}$ ribosomal subunit, we decided to test whether protein synthesis was resistant to the antibiotic in vivo and, for comparison, we used $S$. albus $\mathrm{G}$ as an oleandomycin-sensitive strain ( $\left.\mathrm{MIC} 10 \mu \mathrm{g} \mathrm{ml}^{-1}\right)$. The incorporation of $\left[{ }^{3} \mathrm{H}\right]$ leucine into TCA-insoluble material by mycelium of $S$. albus $\mathrm{G}$ was very sensitive to oleandomycin : $5 \mu \mathrm{g}$ $\mathrm{ml}^{-1}$ caused about $78 \%$ inhibition (Fig. 1). In contrast, the incorporation of $\left[{ }^{3} \mathrm{H}\right]$ leucine by young mycelium of $S$. antibioticus ( $15 \mathrm{~h}$ incubation in minimal medium) was unaffected by oleandomycin concentrations up to $10 \mu \mathrm{g} \mathrm{ml}^{-1}$. With higher concentrations of oleandomycin $\left(\geqslant 25 \mu \mathrm{g} \mathrm{ml}^{-1}\right)$, protein synthesis began to be inhibited. However, the response to the antibiotic changed during the growth cycle, so that with older mycelium (60 $\mathrm{h}$ incubation) protein synthesis was less susceptible (Fig. 1). At this stage of growth oleandomycin production had already commenced (see below). Similar results were found using spores (Fig. 1).

For comparison we also tested the sensitivity of protein synthesis to other MLS antibiotics in mycelium of $S$. antibioticus. Spiramycin, carbomycin, methymycin, erythromycin and lincomycin were strong inhibitors, producing between $72 \%$ and $83 \%$ inhibition at $5 \mu \mathrm{g} \mathrm{ml}^{-1}$.

Evidently, protein synthesis in $S$. antibioticus was selectively resistant to oleandomycin, especially in older mycelium. Therefore, it was desirable to test whether the normal antibiotic target site (i.e. the ribosome) was resistant to the drug. Two different approaches were used: binding of $\left[{ }^{3} \mathrm{H}\right]$ oleandomycin to the ribosomes and assays of the sensitivity of in vitro protein synthesis to oleandomycin.

\section{Preparation of $\left[{ }^{3} \mathrm{H}\right]$ oleandomycin and binding to ribosomes}

In the minimal medium described above, oleandomycin production by $S$. antibioticus started after about $21 \mathrm{~h}$ incubation. Levels of the antibiotic in the supernatant reach a maximum after $60 \mathrm{~h}$ and remained constant for at least the next $30 \mathrm{~h}$ (Fig. 2). We also tried to detect the antibiotic inside the cells. The mycelium was broken by ultrasound and then extracted with chloroform as described in Methods, However, no active oleandomycin could be detected, suggesting either that the drug was being produced within the mycelium as an inactive compound or that intracellular levels of antibiotic were very low. Under these incubation conditions, we prepared $\left[{ }^{3} \mathrm{H}\right]$ oleandomycin by growing the producer organism in the presence of a donor of methyl groups, $\mathrm{L}-\left[\right.$ methyl $\left.-{ }^{3} \mathrm{H}\right]$ methionine. About $2.5 \%$ of the radioactivity initially added was recovered as $\left[{ }^{3} \mathrm{H}\right]$ oleandomycin. The purity of the material was checked by descending paper chromatography: only one radioactive peak was detected, which corresponded with the mobility of reference oleandomycin run in a parallel track and was well separated from a standard of radiolabelled methionine (Fig. 3). Using this material the binding of $\left[{ }^{3} \mathrm{H}\right]$ oleandomycin to the ribosomes of the producer organism ( $S$. antibioticus) and to those of the sensitive organism ( $S$. albus $G$ ) was determined by two methods. By gel filtration it was found that the antibiotic bound to the $70 \mathrm{~S}$ ribosomes of both organisms (data not shown). These results were confirmed by sucrose gradient centrifugation which also showed that the radioactivity was associated with the $50 \mathrm{~S}$ ribosomal subunit (Fig. 4). The addition of an excess of unlabelled oleandomycin completely abolished binding of the radioactive material to the ribosomes, indicating that such binding was not due to non-specific contaminants in the preparation. 


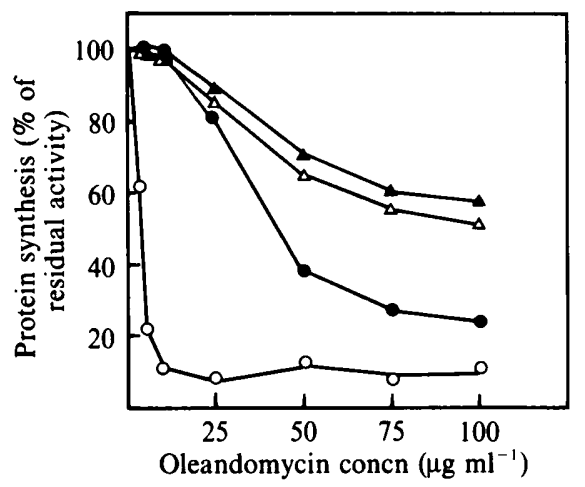

Fig. 1. Effect of oleandomycin on protein synthesis by whole cells. Cell suspensions $(0.5 \mathrm{ml})$ were incubated with the antibiotic for $5 \mathrm{~min}$ before initiating the assay by the addition of $\left[{ }^{3} \mathrm{H}\right]$ leucine $(1 \mu \mathrm{Ci}$ $\mathrm{ml}^{-1}$ ). After $20 \mathrm{~min}$ incubation at $35^{\circ} \mathrm{C}$, the reaction was stopped by adding $1.5 \mathrm{ml}$ of ice-cold $20 \%$ TCA and the radioactivity determined after processing the samples as described in Methods. $O$, $S$. albus $\mathrm{G}, \mathcal{O}, S$. antibioticus, $15 \mathrm{~h}$ incubation; $\triangle, S$. antibioticus, $60 \mathrm{~h}$ incubation; $\Delta, S$. antibioticus spores.

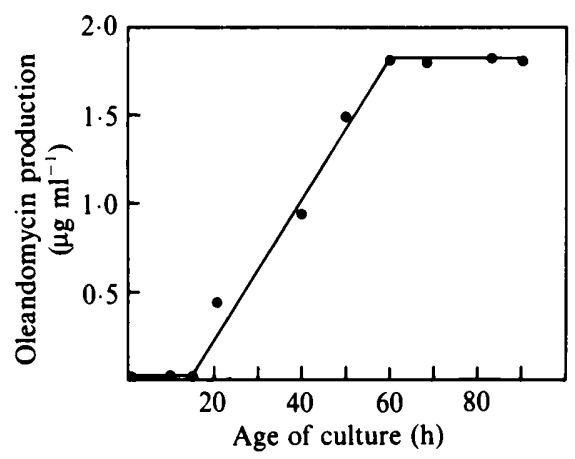

Fig. 2

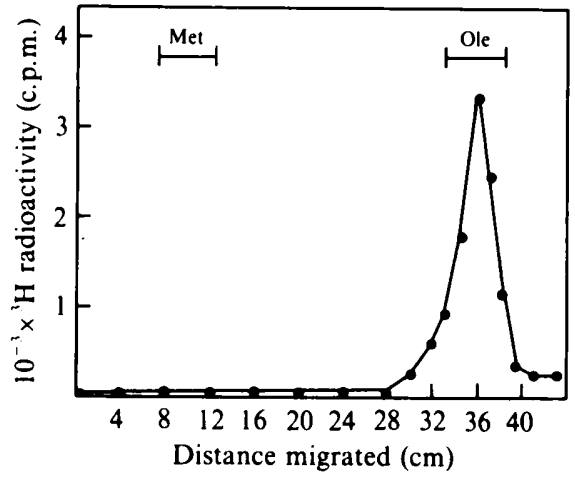

Fig. 3

Fig. 2. Oleandomycin production by $S$. antibioticus. The organism was grown in minimal medium at $35^{\circ} \mathrm{C}$ with shaking. At different times of incubation, samples were removed, centrifuged, and the oleandomycin concentration in the supernatant assayed by bioassay against $M$. luteus.

Fig. 3. Paper chromatography of radioactive oleandomycin. After $72 \mathrm{~h}$ of incubation in minimal medium, the supernatant of a $100 \mathrm{ml}$ culture was extracted with chloroform as described in Methods and the final resultant material applied to Whatman 3MM paper and chromatographed for $15 \mathrm{~h}$ using n-butanol/acetic acid/water $(60: 20: 20$, by vol. as solvent.) After drying, the chromatogram was cut into $1 \mathrm{~cm}$ strips and the radioactivity determined. The position of commercial oleandomycin (Ole) is marked by a horizontal bar as is that for methionine (Met).

\section{Susceptibility of ribosomes to oleandomycin}

Once we knew that the ribosomes of the oleandomycin producer were capable of binding the antibiotic, we examined the functional response of the ribosomes to oleandomycin in vitro. In order to do this, we used a coupled transcription-translation system (Thompson et al., 1984) which is sensitive to a wide range of antibiotics ( $\mathrm{E}$. Cundliffe, personal communication). In contrast, protein synthetic systems directed by artificial mRNA [e.g. poly(U)] have been reported to be relatively insensitive to various macrolides, including oleandomycin (Vázquez, 1966). The coupled system contained S100 (postribosomal $100000 \mathrm{~g}$ supernatant) plus crude initiation factors (see Methods), both from $S$. lividans, plus $70 S$ ribosomes from the different Streptomyces species tested. To these the rest of the components of the coupled system were 


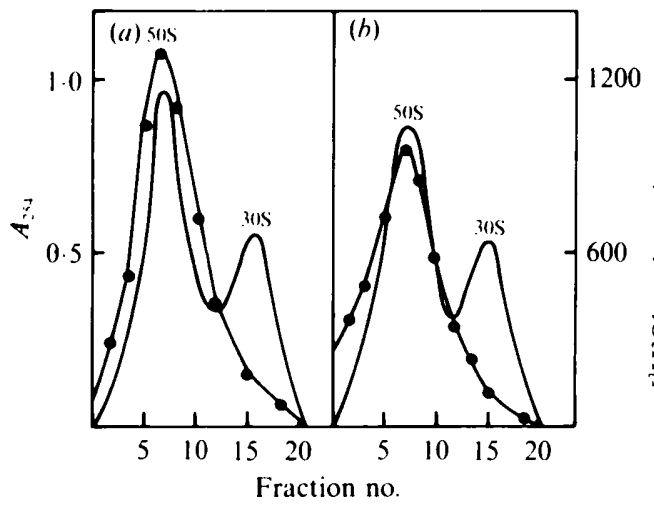

Fig. 4

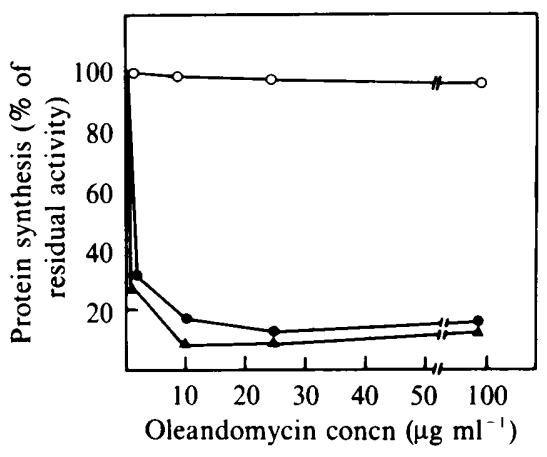

Fig. 5

Fig. 4. Binding of $\left[{ }^{3} \mathrm{H}\right]$ oleandomycin to ribosomes. A sample (5 $A_{254}$ units) of $70 \mathrm{~S}$ ribosomes of $S$. antibioticus $(a)$ or $S$. albus $\mathrm{G}(b)$ was incubated at room temperature for $10 \mathrm{~min}$ with $\left[{ }^{3} \mathrm{H}\right]$ oleandomycin (approximately $167 \mathrm{pmol} ; 598$ c.p.m. pmol $^{-1}$ ). Then, the reaction mixture was layered on to a $5 \mathrm{ml}$ sucrose density gradient (10-30\% sucrose) in $50 \mathrm{mM}-\mathrm{HEPES} / \mathrm{KOH} \mathrm{pH} 7.5$ at $20^{\circ} \mathrm{C}, 1 \mathrm{mM}-\mathrm{MgCl}_{2}$, $150 \mathrm{mM}-\mathrm{NH}_{4} \mathrm{Cl}$ and $5 \mathrm{~mm}$-2-mercaptoethanol. Centrifugation was carried out at $240000 \mathrm{~g}$ for $3 \mathrm{~h}$ in a Beckman SW50.1 rotor and the $A_{254}(-)$ and radioactivity $(O)$ were determined.

Fig. 5. Effect of oleandomycin on in vitro protein synthesis using a coupled transcription-translation system. Ribosomes $\left(30 \mathrm{pmol}\right.$ per $30 \mu \mathrm{l}$ assay) were incubated for $5 \mathrm{~min}$ at $4^{\circ} \mathrm{C}$ with different concentrations of oleandomycin. Then, the incorporation of $\left[{ }^{35} \mathrm{~S}\right]$ methionine into TCA-insoluble material was determined by adding the components of the reaction mixture for the coupled transcription-translation system (Thompson et al., 1984) which was dependent on the addition of plasmid pBR322 $\left(2 \mu \mathrm{g}\right.$ per assay). The mixture was incubated at $30^{\circ} \mathrm{C}$ for $45 \mathrm{~min}$ and duplicate $10 \mu \mathrm{l}$ samples were removed and added to $1 \mathrm{ml}$ of $5 \%$ TCA. After heating at $90{ }^{\circ} \mathrm{C}$ for $15 \mathrm{~min}$, the samples were filtered through Whatman $\mathrm{GF} / \mathrm{C}$ filters and, after drying, the radioactivity determined. Ribosomes were used from the following strains: $S$. albus $\mathrm{G}$ grown for $24 \mathrm{~h}$ in YEME medium (O); $S$. antibioticus grown for $60 \mathrm{~h}$ in oleandomycin-production medium $(A)$; and $S$. erythraeus grown for $24 \mathrm{~h}$ in YEME medium (O).

added (Thompson et al., 1984) and transcription was initiated by adding plasmid pBR322. Using this system we could observe that the ribosomes of both organisms were similarly sensitive to oleandomycin (Fig. 5). As a positive control, ribosomes of $S$. erythraeus (oleandomycin resistant) were also tested and shown to be resistant to the antibiotic (Fig. 5). Ribosomes of $S$. antibioticus were also sensitive to oleandomycin when obtained at three different stages of growth in oleandomycin-production medium (data not shown): i.e. after $15 \mathrm{~h}$ incubation (no oleandomycin production), $36 \mathrm{~h}$ incubation (beginning of oleandomycin production), and $60 \mathrm{~h}$ incubation (maximum levels of oleandomycin production: $1.8 \mu \mathrm{g} \mathrm{ml}^{-1}$ ).

Sensitivity of the ribosomes to oleandomycin was also observed when they were obtained after growing the mycelium under the following culture conditions: YEME medium containing glycerol or succinate as carbon source instead of glucose, YEME medium containing $100 \mu \mathrm{g}$ oleandomycin ml-1 as a possible inducer and GAE sporulation medium (glucose/asparagine/ yeast extract/salts) medium. On the other hand, and, assuming that a relationship could exist between antibiotic production and resistance, ribosomes were also obtained from another solid medium known to support oleandomycin production: GAE solid medium plates (Méndez et al., 1985). In this case, the organism was grown on the top of cellophane films placed on the surface of the agar and, after incubation for $3 \mathrm{~d}$, the cellophane film was removed and the growth on its surface collected. Under these incubation conditions, oleandomycin production by $S$. antibioticus was $3 \mu \mathrm{g} \mathrm{ml}^{-1}$. The results (data not given) clearly showed that, in spite of the fact that oleandomycin was being produced, the ribosomes were susceptible to the antibiotic. 
Table 1. Oleandomycin uptake by mycelium of Streptomyces spp.

Mycelium was incubated at $35^{\circ} \mathrm{C}$ with different concentrations of oleandomycin and, after 0 and $4 \mathrm{~h}$ of incubation, the concentration of oleandomycin in the supernatant was assayed by bioassay against $M$. luteus. In order to make all the assays comparable, the same amount of oleandomycin was added to each tower. Values represent the inhibition halo after subtracting the Oxford tower diameter $(8 \mathrm{~mm})$ and are the mean of three determinations.

\begin{tabular}{|c|c|c|c|c|}
\hline \multirow{3}{*}{$\begin{array}{l}\text { External } \\
\text { oleandomycin conen } \\
\left(\mu \mathrm{g} \mathrm{ml}^{-1}\right)\end{array}$} & \multicolumn{4}{|c|}{ Halo diameter (mm) } \\
\hline & \multicolumn{2}{|c|}{ S. albus $\mathrm{G}$} & \multicolumn{2}{|c|}{ S. antibioticus } \\
\hline & $\mathrm{Oh}$ & $4 \mathrm{~h}$ & $\mathrm{Oh}$ & $4 \mathrm{~h}$ \\
\hline $\begin{array}{r}5 \\
25 \\
50 \\
100\end{array}$ & $\begin{array}{l}15 \\
15 \\
14 \\
14\end{array}$ & $\begin{array}{l}0 \\
0 \\
3 \\
6\end{array}$ & $\begin{array}{l}14 \\
15 \\
14 \\
14\end{array}$ & $\begin{array}{r}14 \\
14 \\
11 \\
8\end{array}$ \\
\hline
\end{tabular}

\section{Assay of inactivating enzymes}

Enzymes have been described which are able to inactivate some antibiotics of the MLS group (Barthelemy et al., 1984; Coats, 1975; LeGoffic et al., 1977). We therefore looked for the possible existence of some oleandomycin-inactivating enzyme in cell-free extracts of $S$. antibioticus. Incubations were carried out at $30{ }^{\circ} \mathrm{C}$ with the $\mathrm{S} 100$ of $S$. antibioticus and the antibiotic in the presence of several compounds which could be necessary as cofactors ( $S$ adenosylmethionine, ATP and acetyl-CoA). By microbiological assay the possible inactivation of the antibiotic was tested using $M$. luteus as the indicator organism; no antibiotic inactivation was detected in this way. Another test for detecting possible inactivation of the drug was also made: $\left[{ }^{3} \mathrm{H}\right]$ oleandomycin was incubated as described above with the $\mathrm{S} 100$ and cofactors and then examined by descending paper chromatography; no alteration in its mobility was detected (data not given).

\section{Oleandomycin uptake}

A clear difference in the incorporation of oleandomycin by mycelium of $S$. antibioticus and $S$. albus $\mathrm{G}$ was observed. At an oleandomycin concentration of $5 \mu \mathrm{g} \mathrm{ml}^{-1}$ more than $95 \%$ of the antibiotic was taken up from the medium by mycelium of $S$. albus $\mathrm{G}$, while the antibiotic remained in the supernatant when incubated with mycelium of $S$. antibioticus (Table 1). The disappearance of oleandomycin from the medium was not due to non-specific binding of the antibiotic to the cell wall of $S$. albus $\mathrm{G}$, since when the experiment was done with broken cells or with the cell wall fraction, the antibiotic was not bound. Further evidence that the antibiotic was being taken up into the cells was provided by the observation that we could recover it after boiling the cells for $5 \mathrm{~min}$ and then centrifuging the culture. The ability of mycelium of the two organisms to incorporate oleandomycin as a function of the external oleandomycin concentration was quite different (Table 1). S. albus $\mathrm{G}$ began to incorporate the antibiotic at low external concentrations while $S$. antibioticus only did so at much higher external levels of the drug.

\section{DISCUSSION}

Three different mechanisms of survival have been reported in antibiotic-producing organisms: (i) modification of the antibiotic target site; (ii) enzymic inactivation of the antibiotic; (iii) exclusion of the antibiotic from the cytoplasm and decrease in cell permeability (for a recent review see Cundliffe, 1984). Resistance by target site modification is a widely employed mechanism in producers of inhibitors of protein synthesis, e.g. erythromycin (Skinner \& Cundliffe, 1982), thiostrepton (Cundliffe, 1978; Cunliffe \& Thompson, 1979), nosiheptide (Cundliffe \& Thompson, 1981), berninamycin (Thompson et al., 1982), and several aminoglycosides (Yamamoto et al., 1981, 1982; Piendl \& Böck, 1982; Skeggs et al., 1985; 
Thompson et al., 1985); this mechanism has also been reported in producers of inhibitors of RNA polymerase (Blanco et al., 1984; Roza et al., 1986). Some examples are also known of enzymic inactivation of the antibiotic by their producers, e.g. streptomycin (Sugiyama et al., 1981), streptothricin (Keeratibipul et al., 1983), viomycin and capreomycin (Skinner \& Cundliffe, 1980), puromycin (Pérez-González et al., 1983; Sugiyama et al., 1985), blasticidin S (Sugiyama et al., 1986) and some aminoglycoside antibiotics (Benveniste \& Davies, 1973; Hotta et al., 1981; Pardo et al., 1985). On the other hand, a decrease in cell permeability to the antibiotic has been suggested to play an important role in self-protection in producers of streptomycin (Sugiyama et al., 1981; Nimi et al., 1981) and chloramphenicol (Malik \& Vining, 1972).

The first mechanism, target site modification, does not seem to be responsible for the resistance of $S$. antibioticus to oleandomycin, since the organism had ribosomes which were able to bind oleandomycin and were susceptible to the antibiotic through all stages of the growth cycle. Therefore, the existence of a constitutive ribosomal resistance to oleandomycin may be ruled out. In the kanamycin-producer. Streptomyces kanamyceticus, ribosomal resistance to kanamycin was only observed when the organism was grown in an antibiotic-production medium (Nakano et al., 1984). Therefore, and in order to discard the possibility that a presumptive inducible ribosomal resistance in $S$. antibioticus was only expressed either when the organism was producing antibiotic or when the antibiotic was acting as exogenous inducer, we tried, unsuccesfully, to induce such a possible ribosomal resistance by growing the organism in oleandomycin-production media or by adding the antibiotic to the medium. Consequently, target site modification can probably be excluded as a self-defence mechanism in S. antibioticus. Also, we could not detect enzymic modification of the antibiotic by extracts of the organism, even after addition of different cofactors. Therefore, intracellular inactivation of oleandomycin by $S$. antibioticus does not seem to be responsible for resistance.

The third possibility for self-resistance, exclusion of the active antibiotic from the cytoplasm and establishment of a permeability barrier, was also tested. $S$. antibioticus showed a reduced permeability to oleandomycin, which had a good correlation with a decreased susceptibility of protein synthesis to the antibiotic during the cell cycle. Whether this represents a general decrease in cell permeability during the late stages of the growth cycle or an oleandomycinspecific decrease, remains unknown. Whatever the mechanism, the results suggest that $S$. antibioticus is not very permeable to oleandomycin. However, the inability to incorporate exogenous antibiotic may be an effective resistance mechanism for a nonproducer strain, but not for a producer organism which must initially resolve the problem of self-protection against antibiotic produced inside the cell. This could be achieved in three different ways. (i) By synthesizing the intracellular antibiotic as an inactive compound which could be activated during excretion; such a mechanism has been reported for streptomycin biosynthesis (Miller \& Walker, 1969; Piwowarski \& Shaw, 1979; Sugiyama et al., 1981). (ii) By the location of the toxic product within subcellular compartments during biosynthesis. (iii) If the antibiotic is produced as an active compound, there could exist a cooperation between antibiotic production and excretion so that the levels of antibiotic inside the cells would be prevented from reaching values capable of blocking cell growth. In S. antibioticus we do not yet know which of these mechanisms could be participating in the elimination of oleandomycin from the cytoplasm where sensitive ribosomes are present. It is possible that the antibiotic is synthesized as an inactive compound, since we were unable to detect active oleandomycin inside the cells at the time when maximum levels of the drug were being produced, but this will require further proof.

We are very grateful to Mike Calcutt for introducing us to the use of the coupled transcription-translation system. This work was supported in part by a grant of the Comision Asesora para el desarrollo de la Investigación Cientifica y Técnica (CAICYT no. 2107/83) and by an Acción Integrada Hispano-Británica no. 18/23.

\section{REFERENCES}

Barthelemy, P., Autissier, D., Gerbaud, G. \& Courvalin, P. (1984). Enzymic hydrolysis of erythromycin by a strain of Escherichia coli. A new mechanism of resistance. Journal of Antibiotics 37, 1692-1696.

Benveniste, R. \& Davies, J. (1973). Aminoglycoside 
antibiotic-inactivating enzymes in actinomycetes similar to those present in clinical isolates of antibiotic-resistant bacteria. Proceedings of the National Academy of Sciences of the United States of America 70, 2276-2280.

Blanco, M. G., Hardisson, C. \& Salas, J. A. (1984). Resistance to inhibitors of RNA polymerase in the actinomycetes that produce them. Journal of General Microbiology 130, 2883-2891.

Clewell, D. B. \& Franke, A. E. (1974). Characterization of a plasmid determining resistance to erythromycin, lincomycin, and vernamycin $B \alpha$ in a strain of Streptococcus pyogenes. Antimicrobial Agents and Chemotherapy 51, 534-537.

CoAts, J. H. (1975). Clindamycin phosphotransferase. Methods in Enzymology 43, 755-759.

Cundliffe, E. (1978). Mechanism of resistance to thiostrepton in the producing organism Streptomyces azureus. Nature, London 272, 792-795.

CundlifFe, E. (1984). Self defence in antibioticproducing organisms. British Medical Bulletin $\mathbf{4 0}$, 61-67.

Cundliffe, E. \& Thompson, J. (1979). Ribose methylation and resistance to thiostrepton. Nature, London 278, 859-861.

Cundliffe, E. \& Thompson, J. (1981). The mode of action of nosiheptide (multhiomycin) and the mechanism of resistance in the producing organism. Journal of General Microbiology 126, 185-192.

Gale, E. F., Cundliffe, E., Reynolds, P. E., RICHMOND, M. H. \& WARING, M. J. (1981). The Molecular Basis of Antibiotic Action, 2nd ed. London: Wiley.

GrahaM, M. Y. \& Weisblum, B. (1979). 23S Ribosomal ribonucleic acid of macrolide-producing streptomycetes contains methylated adenine. Journal of Bacteriology 137, 1464-1467.

Hotta, K., Yamamoto, H., OKami, Y. \& Umezawa, H. (1981). Resistance mechanisms of kanamycin-, neomycin- and streptomycin-producing streptomycetes to aminoglycoside antibiotics. Journal of Antibiotics 34, 1175-1182.

Keeratibipul, S., SugiYama, M. \& Nomi, R. (1983). Mechanism of resistance to streptothricin of a producing microorganism. Biotechnology Letters 5 , 441-446.

LAI, C. J. \& Weisblum, B. (1971). Altered methylation of ribosomal RNA in an erthromycin-resistant strain of Staphylococcus aureus. Proceedings of the National Academy of Sciences of the United States of America 68, 856-860.

LAI, C. J., Weisblum, B., FahNestock, S. R. \& Nomura, M. (1973). Alteration of 23S ribosomal RNA and erythromycin-induced resistance to lincomycin and spiramycin in Staphylococcus aureus. Journal of Molecular Biology 74, 67-72.

LeGoffic, F., Capmau, M. L., Abbe, J., Cerceau, C., Dublanchet, A. \& Duval, J. (1977). Plasmidmediated pristinamycin resistance: $\mathrm{PH} 1 \mathrm{~A}$, a pristinamycin IA hydrolase. Annales de Microbiologie 128, 471-474.

MALIK, V.S. \& Vining, L. C. (1972). Chloramphenicol resistance in a chloramphenicol producing Streptomyces. Canadian Journal of Microbiology 18, 583-590.

Méndez, C., Braña, A., Manzanal, M. B. \& HaRdisson, C. (1985). Role of substrate mycelium in colony development in Streptomyces. Canadian Journal of Microbiology 31, 446-450.

Miller, A. L. \& J. B. W AlKer (1969). Enzymatic phosphorylation of streptomycin by extracts of streptomycin-producing strains of Streptomyces. Journal of Bacteriology 99, 401-405.

Nakano, M. M., Mashiko, H. \& Ogawara, H. (1984). Cloning of the kanamycin resistance gene from a kanamycin-producing Streptomyces species. Journal of Bacteriology 157, 79-83.

Nimi, O., Sugiyama, M., Kameoka, H., Tomoeda, H., ONo, K. \& Noml. R. (1981). Fate of streptomycin in mycelium of producer organism. Biotechnology Letters 3, 239-244.

Pardo, J. M., Malpartida, F., Rico, M. \& Jiménez, A. (1985). Biochemical basis of resistance to hygromycin B in Streptomyces hygroscopicus - the producing organism. Journal of General Microbiology 131, 1289-1298.

Pérez-González, J. A., Vara, J. \& Jiménez, A. (1983). Acetylation of puromycin by Streptomyces alboniger, the producing organism. Biochemical and Biophysical Research Communications 113, 772-777.

PIENDL, W. \& BöCK, A. (1982). Ribosomal resistance in the gentamicin producer organism Micromonospora purpurea. Antimicrobial Agents and Chemotherapy 22, 231-236.

Piwowarski, J. M. \& Shaw, P. D. (1979). Streptomycin resistance in a streptomycin-producing microorganism. Antimicrobial Agents and Chemotherapy 16, 176-182.

Roza, J., Blanco, M. G., Hardisson, C. \& Salas, J. A. (1986). Self-resistance in actinomycetes producing inhibitors of RNA polymerase. Journal of Antibiotics 39, 609-612.

Skeggs, P. A., Thompson, J. \& Cundliffe, E. (1985). Methylation of $16 \mathrm{~S}$ ribosomal RNA and resistance to aminoglycoside antibiotics in clones of Streptomyces lividans carrying DNA from Streptomyces tenjimariensis. Molecular and General Genetics 200 , 415-421.

SkinNer, R. H. \& Cundliffe, E. (1980). Resistance to the antibiotics viomycin and capreomycin in the Streptomyces species which produce them. Journal of General Microbiology 120, 95-104.

SKINNER, R. H. \& CUNDliffe, E. (1982). Dimethylation of adenine and the resistance to erythromycin in the producing organism. Journal of General Microbiology 128, 2411-2416.

SKinNer, R. H., Cundliffe, E. \& Schmidt, F. J. (1983). Site of action of a ribosomal RNA methylase responsible for resistance to erythromycin and other antibiotics. Journal of Biological Chemistry 258, 12702-12706.

SugiYama, M., Mochizuki, H., Nimi, O. \& Nomi, R. (1981). Mechanism of protection of protein synthesis against streptomycin inhibition in a producing strain. Journal of Antibiotics 34, 1183-1188.

Sugiyama, M., PaIk, S. \& Nomi, R. (1985). Mechanism of self-protection in a puromycin-producing micro-organism. Journal of General Microbiology 131, 1999-2005.

Sugiyama, M., Takeda, A., PaIk, S., Nimi, O. \& NoMI, R. (1986). Acetylation of blasticidin $S$ by its producing actinomycetes. Journal of Antibiotics 39, 827-832. 
Thompson, J., Cundliffe, E. \& Stark, M. J. R. (1982). The mode of action of berninamycin and the mechanism of resistance in the producing organism, Streptomyces bernensis. Journal of General Microbiology 128, 875-884.

Thompson, J., RAE, S. \& CUNDliffe, E. (1984). Coupled transcription-translation in extracts of Streptomyces lividans. Molecular and General Genetics 195, 39-43.

Thompson, J., Skeggs, P. A. \& Cundliffe, E. (1985). Methylation of $16 \mathrm{~S}$ ribosomal RNA and resistance to the aminoglycoside antibiotics gentamicin and kanamycin determined by DNA from the gentamicin-producer, Micromonospora purpurea. Molecular and General Genetics 201, 168-173.
VÁzquez, D. (1966). Antibiotics affecting chloramphenicol uptake up bacteria. Their effect on amino acid incorporation in a cell-free system. Biochimica et biophysica acta 114, 289-295.

YамAMOTo, H., НоTta, K., OKami, Y. \& Umezawa, H. (1981). Ribosomal resistance of an istamycin producer, Streptomyces tenjimariensis, to aminoglycoside antibiotics. Biochemical and Biophysical Research Communications 100, 1396-1401.

Yamamoto, H., Hotta, K., Okami, Y. \& Umezawa, H. (1982). Mechanism of resistance to aminoglycosides in nebramycin-producing Streptomyces tenebrarius. Journal of Antibiotics 35, 1020-1025. 